\title{
EAl Endorsed Transactions

\section{An architectural framework of a Decision Support System (DSS) to increase the returns of small scale farmers in Kanchipuram District, India}

\author{
K.Sornalakshmi*, S.Sindhu, G.Sujatha, D.Hemavathi \\ School of Computing, SRM Institute of Science and Technology, Kattankulathur, India
}

\begin{abstract}
In India, $80 \%$ of farmers are small scale and marginal farmers. The sub section of these farmers who cultivate vegetables do not get considerable returns on their investment because their produce has to pass through various layers of agents or distributors before reaching the end users. This process could be regulated to minimize round trip transfer of vegetables for the sake of increased farmer returns. Also, many farmers cultivate the same crop resulting in over production which in turn affects the returns of all farmers cultivating that crop. There are many government schemes like FPOs (Farmer Producer Organizations), PPC (Primary Processing Centers), SFAC (Small Farmers Agri Consortium) to cater this issue. This paper surveys all the existing schemes and mobile platforms. We also propose a framework for a holistic mobile app based decision support system for small scale farmers.. This proposed application helps the farmers to increase the returns without middleman and promote community farming.
\end{abstract}

Keywords: Supply Chain Management, smart agriculture, agri-marketing, Green Massive MIMO Techniques, Green Communication Protocols

Received on 05 March 2020, accepted on 01 April 2020, published on 14 April 2020

Copyright (C) 2020 K.Sornalakshmi et al., licensed to EAI. This is an open access article distributed under the terms of the Creative Commons Attribution license, which permits unlimited use, distribution and reproduction in any medium so long as the original work is properly cited.

doi: 10.4108/eai.13-7-2018.163978

*Corresponding author. Email:sornalak@srmist.edu.in

\section{Introduction}

Farmers play a vital role in national development since the major occupation of India is agriculture. Farmers face many issues in their day to day life to sell their produce with nominal profit. Even though India is an agricultural country, agricultural marketing is not so optimized. The
Indian farmers are not benefited properly for their hard work because of many middlemen. The middlemen purchase the commodities at lower price from the farmer and on the other side, they demand higher prices from end users. The communication among farmers is very poor. The middleman are easily exploiting the farmers and they do not get a good or even nominal price for their produce, even though they are aware that the middleman are 
getting good price for their products from the end user. There is a lack of properly organized marketing system. Because of lack of transport facilities, the farmers are unable to reach the appropriate market to get good price for their produce. The future trend of agriculture will continue to be dominated by small scale farmers. The supply chain management and agri marketing $[10,11]$ is highly complicated since most of the farmers depend on man in the middle for selling their produce. Though there are many efficient government schemes [1-4,8] that attend to most of the farmer needs, earlier farmers showed low interest in such schemes due to practical difficulties, transportation, technology barriers and ignorance. Since usage of mobile technology by the farmers have shown a considerable increase now an integrated decision support system in the farmer's mobile would be more usable and practical. It is also necessary to provide mobile app based and field based training for the small scale farmers. The major problems of a small scale or marginal farmers are ensuring anytime marketing of their produce with considerable returns. Breaking down this problem, it could be observed that - knowing the sellers, fixing a reasonable price for their harvest based on market price and optimal transportation are the key areas in which farmers require decision support in the Indian agri-market context. In this work, a mobile based decision support system is to be designed for small scale/marginal farmers in India which addresses their optimal decision process in marketing their produce.

\section{Related work}

The Indian Government has taken many steps to improve the agriculture and providing benefits at large scale. The major schemes for agricultural marketing provided by Indian government are:

1. Integrated scheme for Agricultural marketing (2014).

2. National Agriculture Market (e-NAM).

3. Model Agricultural Produce and Livestock Marketing (promotion and Facilitation) Act 2017.

In this work, maximum schemes and existing apps were analyzed, and could find that the schemes will increase the profit of large scale farmers. The problem is for small scale farmers only. So, we try to identify and fill the gap existing in this regard. There is a need to conduct in depth research covering specific marketing problems of small scale farmers which could also include livestock.

\section{Government Schemes for small scale farmers:}

\section{Farmer Producer Organization(FPO):}

FPO is an entity especially formed by primary producers. An FPO can be a producer company, like cooperative society or any other legally approved organization which helps in providing share in profits among the members of the organization.

The important objective of an FPO is to improve and provide assured profit through this organization which is created and maintained by their own. As an individual, a small farmer cannot yield good profit for their produce even after their hard work because of numerous intermediates who buy the farmer produce with small value and demand more from end customers.

Roles of FPOs:

It acts as a collection centre to aggregate the produce from various farmers.

- It facilitates the farmer members of this organization in many ways.

- Since it is created and maintained by the farmers, they will remain as owners.

- They are doing preprocessing before marketing like basic cleaning of their commodities to improve their price.

- $\quad$ They aggregate the produce from various farmers and segregate the commodities of different qualities of same type as separate lots

- They provide transport facility from collection centre to nearest e-NAM mandi.

Benefits of FPOs:

- Transparency in trade.

- Access to larger numbers of buyers.

- Inter Mandi Trade

- Intra Mandi Trade

- Correct Weighment

- Timely Payment

- Getting Information Regarding Trade through their mobile phone

Small Farmers Agri-Business Consortium(SFAC):

It focused mainly in improving incomes of small and marginal farmers through aggregation and development of Agri business. It is responsible for the formation and maintenance of FPOs. It offers schemes like Equity grant and credit guarantee fund scheme to FPOs to improve their investment capital and increase their profit.

It also implements e-NAM a unified market for agricultural products with better price. The SCM cell of Agricultural department is planned to propose PPS for Farmer welfare. PPS - Pre Processing service center helps in preprocessing their product before marketing to improve their cost realization. Through this PPS, government planned to provide the infrastructure for storing, doing preprocessing and planned to provide machineries to do value additions from their commodities. They try to connect FPOs and PPS to improve the farmer Agri-Marketing.

Role of NGOs in helping farmers:

Many NGOs are also helping farmers market theor produce. The requirements for this work and the current situation were majorly obtained from farmers through an 
NGO - AHIMSA (All Human Integrated Meritorious Social Awareness) one of the popular NGO for coordinating interested farmers for data collection, testing and feedback.

\section{Government E-Applications for facilitating agri- marketing \\ - $\quad$ eNAM[1]}

eNAM networks the existing mandi to create a unified national market for agricultural commodities. Purpose of the mobile App is to facilitate remote bidding by traders and access to arrivals and price related information to farmers and other stakeholders on their smart phones.

\section{- Demic[2]}

The Domestic and Export Market Intelligence Cell (DEMIC) collects real time data on arrivals, prices and transaction of important agricultural commodities from Regulated Markets in Tamil Nadu, conducting market surveys, compiling commodity reports and assessing export opportunities of agricultural commodities.

\section{- $\quad$ eAdangal[3]}

Adangal, a document containing information about the details of the farmlands in the villages. Adangal is a very important revenue record, as it contains details of land such as owner's details, area, assessment, water rate, soil type, nature of possession of the Land, Liabilities, Tenancy and Crops grown, etc. eAdangal is an app to maintain the record electronically.

\section{Research on agri-marketing}

In this work [10], the author facilitates professional management practice and researchers to uncover and explore the enablers for the real execution of sustainability oriented initiatives in the agri-food business sector. An empirical case study, drawn from a vegetable and fruit retail supply chain in India, is used to focus and test the applicability of the proposed research framework.

In this paper [11] author discuss about the price risk of agricultural production. Agricultural futures price plays a very important role in the augment of farmer incomes, the adjustment of agricultural structure and the improvement of the core competitiveness of agriculture. So, how to improve the agricultural futures markets to provide better services for the agriculture, rural areas and farmers has become an issue. This paper summarizes the existing models, and learn from the food chain theory to make an integration study of the service models and then explore the models with more practical value.

The main objective of this study [12] is to investigate the hypothesis that individuals have greater relative preferences for the environmental benefits associated with agri-environment schemes when they are delivered within those landscapes closest to where they live. A choice experiment approach based on a national survey provides the data and a mixed legit approach is used to model relative preferences for the environmental benefits of ES across five generic landscape types. Results show that most respondents have a preference for benefits delivered in those areas closest and most accessible to where they live.

The paper [13] offers insights that can inform governments about the incentives required to bring about change. In addition, the paper illustrates the novel application of a choice experiment to enumerating the perceived costs of changes in vegetable supply chains.

Though decision support systems are widely used in other domains, recent works are using DSS in agriculture as well. AgroDSS[14] surveys how decision support systems and artificial intelligence can be used in precision agriculture. Modern vertical and indoor farms are using DSS for their irrigation and horizontal requirements[15].

Decision Support systems have also been used in cost estimation for farm machinery and break analyzer[16].The study finds way to improvise youth participation by using modern technology in agriculture. it surveys all computer engineering tools in agriculture[17]. Decision support systems for farmers have been proved useful in many instances. One such DSS [18] help the farmers in selecting crops, disease surveillance, recommendations on pest control, choosing appropriate fertilizers and so on.

Managing supply chain in terms consumption driven produce is a key challenge in agri-marketing. A detailed investigation on the dynamic Indian market is necessary to frame a decision support system to help farmers [19].

\section{Existing Mobile Applications for farmers:}

Existing mobile applications that are technical assistant to farmers provide various benefits to the farming community as summarized in Table 1. These applications can be grouped under major three categories - Weather Prediction, Crop Advisory and Marketing. Out of the marketing applications, there is no dedicated regional mobile application that assists the production and supply chain of small scale and marginal farmers without concentrating on the large scale farmers at mandi level. Since the production size of large scale farmers is huge, their marketing and transportation is not a burden to them. But for small scale vegetable farmers, their production is limited and seasonal. A mobile based decision support exclusively for fruits and vegetables (perishables) in the context of small and marginal farmers would really benefit the farming community at large.

\section{Proposed system}

The mobile app based decision support system for farmers require the support for marketing decisions, planting decisions and discussion forums. The components of the mobile app are:

Plantation - Farmers can get quantitative details on the plantation choices based on historical and current data on 
spatiotemporal profit corresponding to suggested crops.

Marketing decision support - To enable the small scale farmers market their produce with optimal returns to the nearby small scale buyers/distributors/firms. Plantation decision support - To provide suggestions to farmers to decide which crop to plant based on historical profit data in the area and live plantation data (eAdangal).

Video/Audio Based discussion forums - To enable farmers to share their success stories or queries in audio or video format to other users. The other users could reply, report or get knowledge from the farmer experience. Same is applicable for buyers and transport operators as well. The farmers have to be given field based training to create Farmer Interest Groups for collective farming to achieve balanced produce.

Optimal transportation - The usage of shortest route algorithms like Minimum spanning Tree for finding shortest transport route of produce to end users or sellers has to be investigated. Produce from multiple farmers on the route who require only delivery to any seller could be consolidated to minimize transport cost.

Optimized Profit/ Returns Model-Optimization techniques like linear Programming and genetic algorithms are to be used to decide the optimal farmer and buyer mapping for maximum profit.

Time Series Prediction - Advanced analytics teschiques could be used for spatio temporal prediction of requirement of fruits and vegetables to plan cultivation. Time series analysis techniques and algorithms like ARIMA (Auto Regressive Integrated Moving Average) and LSTM (Long Short Term Memory networks) along with content based or collaborative filtering methods could provide promising results.

The innovative elements in the proposed framework are:
- $\quad$ Optimal returns to farmers by mapping farmers produce to nearest distributor.

- Maximum win-win profit mapping between buyers and farmers.

- $\quad$ Exclusively done for small scale and marginal farmers.

- $\quad$ Customized plantation recommendations that includes farmer group of interests and live plantation data in the area.

- $\quad$ Optimal transportation by combining farmers and buyers in the same area and hence deciding.

The target beneficiaries of the framework are small scale/marginal farmers, small scale buyers/distributors, Department of Agriculture - Agri-business and marketing, Horticulture 
Table 1. Existing mobile applications for farmer

\begin{tabular}{|c|c|c|c|c|c|c|}
\hline $\begin{array}{c}\text { APPLICATION } \\
\text { NAME }\end{array}$ & FEATURES & DOWNLOADS & $\begin{array}{l}\text { MAJOR } \\
\text { FOCUS }\end{array}$ & OFFERED BY & PROS & CONS \\
\hline ENam [1] & 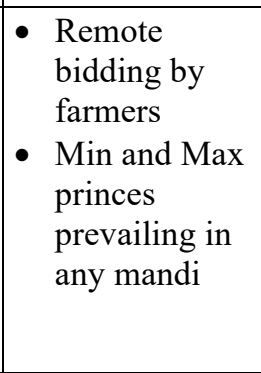 & $50000+$ & $\begin{array}{l}\text { Agriculture } \\
\text { Marketing }\end{array}$ & $\begin{array}{l}\text { Small farmers } \\
\text { AGRI Business } \\
\text { consortium }\end{array}$ & $\begin{array}{l}\text { Real time price } \\
\text { discovery based } \\
\text { on actual demand } \\
\text { and supply. }\end{array}$ & $\begin{array}{l}\text { - Mandi details } \\
\text { are not up to } \\
\text { date for all } \\
\text { states } \\
\text { - No proper } \\
\text { notification } \\
\text { signals for } \\
\text { traders while } \\
\text { they bid }\end{array}$ \\
\hline $\begin{array}{l}\text { KisanSuvidha } \\
\text { [4] }\end{array}$ & $\begin{array}{l}\text { - weather alerts } \\
\text { like } \\
\text { hailstorms or } \\
\text { unseasonal } \\
\text { rains } \\
\text { - market price, } \\
\text { (Mandi) } \\
\text { - plant } \\
\text { protection } \\
\text { (Controls Pest } \\
\text { Attack)and } \\
\text { - Expert } \\
\text { advisories }\end{array}$ & $500000+$ & $\begin{array}{l}\text { Better } \\
\text { Farming }\end{array}$ & Mobile App Seva & $\begin{array}{l}\text { Easy to get crop } \\
\text { information and } \\
\text { timely } \\
\text { management of } \\
\text { crop fertilizers }\end{array}$ & \begin{tabular}{|lr} 
- & Not good for \\
plant based \\
Advisory \\
services. \\
- Real r time \\
discovery for \\
market prices \\
was r not \\
discussed.
\end{tabular} \\
\hline PusaKrishi [5] & $\begin{array}{l}\text { Weather } \\
\text { Prediction } \\
\text { new varieties } \\
\text { of crops } \\
\text { developed by } \\
\text { Indian council } \\
\text { of agriculture } \\
\text { - resource- } \\
\text { conserving } \\
\text { cultivation } \\
\text { practices }\end{array}$ & $100+$ & $\begin{array}{l}\text { Weather } \\
\text { prediction } \\
\text { \&Advisory } \\
\text { for crop }\end{array}$ & CDAC-Mumbai & $\begin{array}{l}\text { Helps in queries } \\
\text { resolution from } \\
\text { farmers }\end{array}$ & $\begin{array}{l}\text { - Real time } \\
\text { discovery for } \\
\text { market prices } \\
\text { was not } \\
\text { discussed. }\end{array}$ \\
\hline AGRI APP [6] & $\begin{array}{ll} & \text { Crop } \\
\text { production } \\
\text { - } \\
\text { Crop } \\
\text { protection }\end{array}$ & $100000+$ & $\begin{array}{l}\text { Crop } \\
\text { protection }\end{array}$ & $\begin{array}{l}\text { Agriapp } \\
\text { Technologies }\end{array}$ & $\begin{array}{l}\text { Useful for } \\
\text { collecting } \\
\text { information about } \\
\text { Bio fertilizers }\end{array}$ & $\begin{array}{l}\text { - Problem with } \\
\text { live chatting }\end{array}$ \\
\hline NAPANTA [7] & $\begin{array}{l}\text { Dynamic } \\
\text { information } \\
\text { pertaining to } \\
\text { daily market } \\
\text { price } \\
\text { - Prevention of } \\
\text { diseases } \\
\end{array}$ & $100000+$ & $\begin{array}{l}\text { Prevention } \\
\text { of diseases }\end{array}$ & $\begin{array}{l}\text { FarmgreenAgritech } \\
\text { India pvt ltd. }\end{array}$ & $\begin{array}{l}\text { - Useful for } \\
\text { pesticide } \\
\text { management } \\
\text { - Natural } \\
\text { farming list }\end{array}$ & $\begin{array}{l}\text { - Weather } \\
\text { prediction } \\
\text { status } \\
\text { - Need daily } \\
\text { update for } \\
\text { market price }\end{array}$ \\
\hline UZHAVAN [8] & $\begin{array}{l}\text { - } \text { subsidy } \\
\text { pattern of } \\
\text { assistance } \\
\text { - weather } \\
\text { forecast } \\
\text { advisories } \\
\text { - J farm } \\
\text { services }\end{array}$ & $100000+$ & $\begin{array}{l}\text { Crop } \\
\text { insurance }\end{array}$ & $\begin{array}{l}\text { Agriculture } \\
\text { Department, Tamil } \\
\text { Nadu }\end{array}$ & $\begin{array}{l}\text { Comfortable for } \\
\text { enquiring about } \\
\text { subsidy items }\end{array}$ & $\begin{array}{l}\text { - No real time } \\
\text { discovery for } \\
\text { market prices. }\end{array}$ \\
\hline
\end{tabular}




\begin{tabular}{|l|l|l|l|l|l|l|}
\hline PLANTIX [9] & $\bullet \begin{array}{l}\text { Crop } \\
\text { Advisory } \\
\bullet \begin{array}{l}\text { Health check } \\
\text { for plants }\end{array}\end{array}$ & 5000000 & $\begin{array}{l}\text { Recognizes } \\
\text { the plant } \\
\text { disease }\end{array}$ & PEAT GmbH & $\begin{array}{l}\text { Comfortable } \\
\text { platform for } \\
\text { detection and } \\
\text { diagnosis of plant } \\
\text { disease }\end{array}$ & $\begin{array}{l}\bullet \text { Misintrepation } \\
\text { of plant } \\
\text { images } \\
\text { Not updated } \\
\text { for all crop } \\
\text { types }\end{array}$ \\
\hline
\end{tabular}




\section{Methodology}

A user friendly mobile app that hosts a DSS for supporting the famer's decision making process in choosing the crop for cultivation and marketing the product is to be designed. Multiple authenticated farmers post the availability of produce and interested buyers can opt for it till the pooling time (12 PM on the day of delivery) of the produce. After the pooling time, when multiple buyers have chosen the same farmer, a bidding process is initiated and farmer-buyer mapping is finalized based on highest benefit to farmer. The farmer and buyers are grouped according to the shortest route and the one covering most of the farmers and buyers. Consolidated routes are then communicated to the transport person.

The proposed mobile application is a cross-platform mobile app that hosts a decision support system for plantation and marketing decisions. It has the below technical specifications:

- $\quad$ Language preferences - Tamil and English options available

- Geo-Location Services - Used to track the location of farmer and buyer to calculate the distance between them and their cost of operation.

- Push/Pull notifications - Send push notification to all registered buyers on farmer postings. Farmer and buyer can exchange messages during bidding.

- Maps - Can show the route of transfer to farmer and producer. Also used to find the shortest route.

- $\quad$ Payment Options - BHIM/UPI

- Usability - Most of the menu items are having single word(Tamil/English) and pictures to enable ease of use

- Data Caching - In case the farmer does not have data connection in field, he can post which will be saved in a local light weight database and pushed to server when data connection is available

- Discussion Forums - Audio/Video based discussions apart from text

- Dashboard Reports - Farmer/Buyer trends. Vegetable plantation trends and profit trends over the past years.

The benefits for Producers (Farmers) through the mobile app are multifold like Direct sale to nearby buyers, Optimized Selling Process, ROI improvement, Reduced Transportation complexity via transport pooling, Demand Based Production

\section{Application Architecture}

The architecture of the DSS mobile app is give in Figure 1. The targeted specifications for the mobile app are User friendliness, Native language support, Increased profit of small scale farmers. The app is to be developed and tested in the cloud set up so that the farmers can access the app from their phones. The app is to be tested with all major OS Apple, iOS and Android. The backend for the mobile application is to be hosted on cloud platform which has the presentation layer, application layer and database layer. The application backend also communicated with Google map API for route optimization module. The reporting module fetches data from the database in different visualization formats and tables. Umbrella layers like Configuration, Security and Access Management are done according to the cloud service provider.

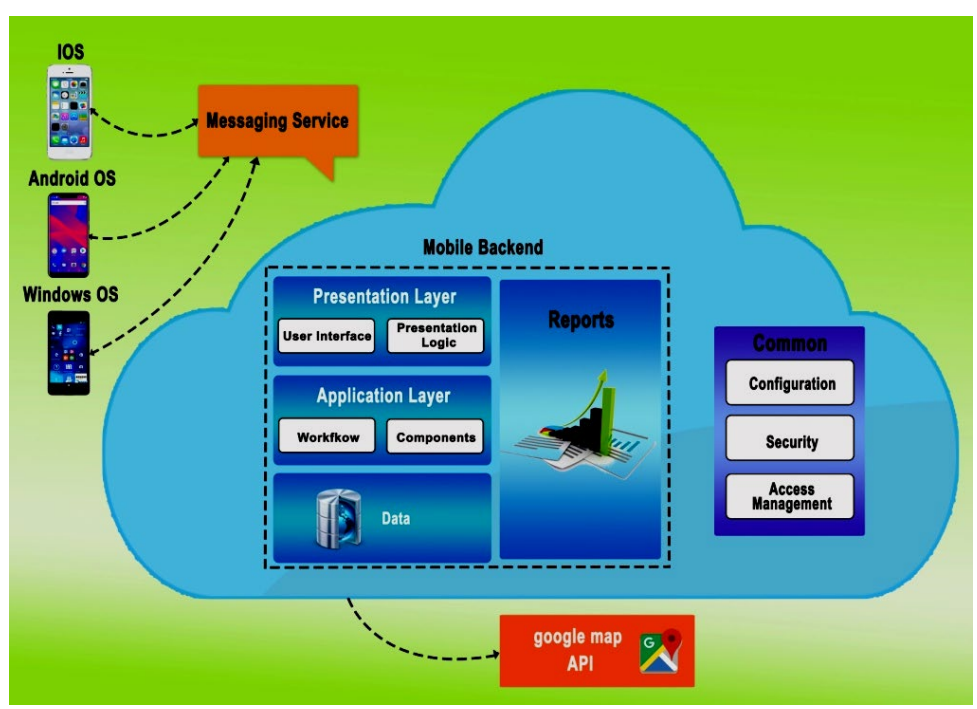

Figure 1. Mobile Application Architecture

This research work will get success in the farmer's society to improve their return on investment in an efficient way. Mobile app will be helpful for the farmers to identify their buyer in nearby locations. They can able to market their vegetables in an optimized way. Bidding option is mainly used for farmers to improve their returns. Chain of middleman cost could also be reduced. Transportation pooling is also a highlighted task in this mobile app. During opinion collection process with farmers from Orathi area, Kancheepuram district, Tamilnadu, the farmers specified difficulty in marketing their produce with good profit. This app design focused to overcome all the problems of farmers in marketing side. So definitely the app will be useful to the farmers. The process flow diagram of the proposed mobile app is 
given in Figure 2. The major modules include farmer registration, accessing buyer cart, bidding for goods and optimal price fixation, optimizing transport routes so that maximum returns is obtained by the farmer, online payment facilities to the farmers.

There are two primary objectives for the proposed mobile app. The first objective of the decision support system is to help farmers in marketing their produce. The second objective is to use the decision support system to reduce surplus production.

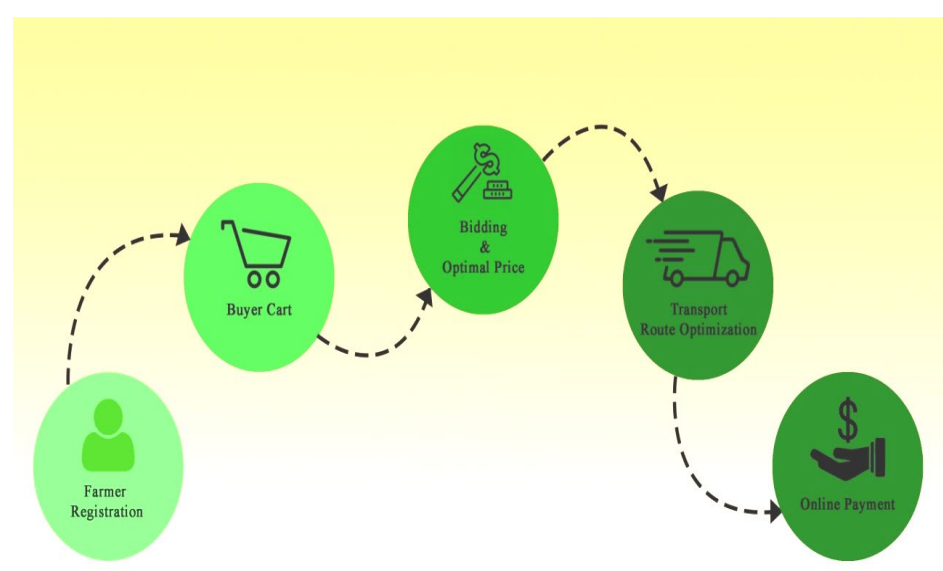

Figure 2. Process flow diagram of our proposed decision support system

The working principle of the DSS in terms of marketing is shown in Figure 3

1. Farmers post the produce details in the format of $<$ Commodity, Quantity, Tentative Price $>$

2. Distributors/Agents/Consumers post the demand in the format of $<$ Commodity, Quantity $>$

3. A push notification to all relevant distributors in the format of $<$ Commodity, Quantity, Tentative Price $>$. The tentative price varies for each distributor based on the distance between farmer and distributor. This price is fixed based on Wholesale Price, Retail Price and UzhavarSandhai price (Regulated Price) and Transport Price.

4. The distributors prepare a tentative cart list choosing farmers and commodity quantity in the format $[<$ Farmer, Commodity, Quantity, and Transport Option>]. Transport option is selected by distributor own or pooled transport. Only one option for one distributor.

5. This cart preparation closes after the pooling time says 12 PM every day.

6. After $12 \mathrm{PM}$, the multiple mappings are resolved using live bidding as in eNAM.

7. The optimized transport route is calculated by clubbing multiple farmers and distributors.

8. The final cost based on 6 and 7 is calculated and communicated to both farmers and distributors.

9. Bid history can be viewed by both farmers and buyers.

10. Once the bills are generated for winning lot the buyer can view their pending invoices.

The flow of the second objective for reducing surplus production is shown in Figure 4.

1. Farmers enter input as follows

- Time of Sowing

- Current Plantation

- Farmer chosen vegetable

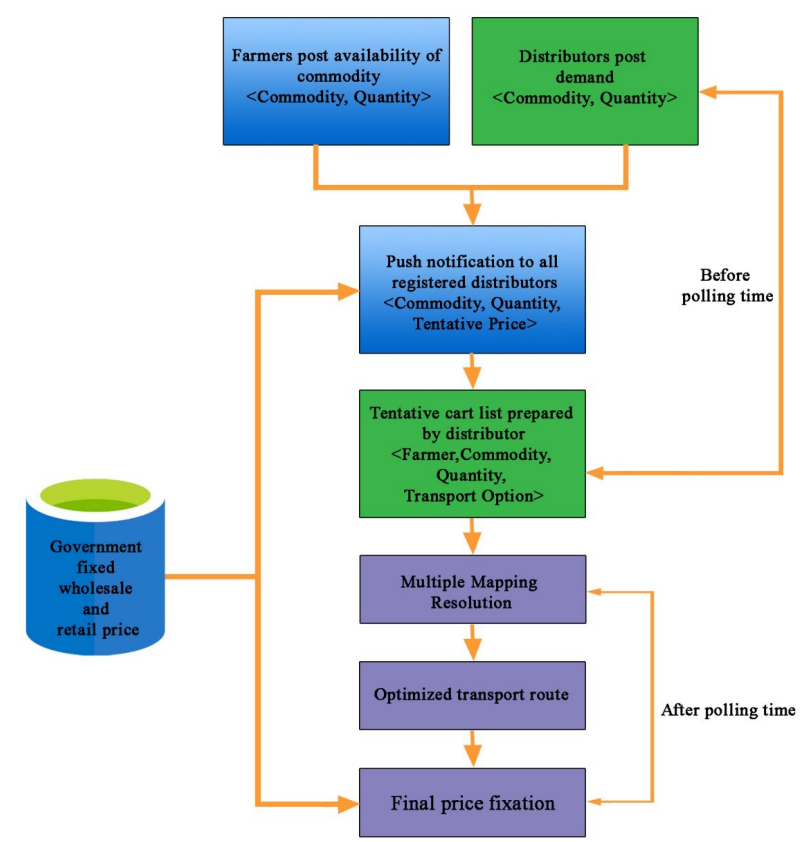

Figure 3. Working Principle of Proposed Framework DSS for marketing 


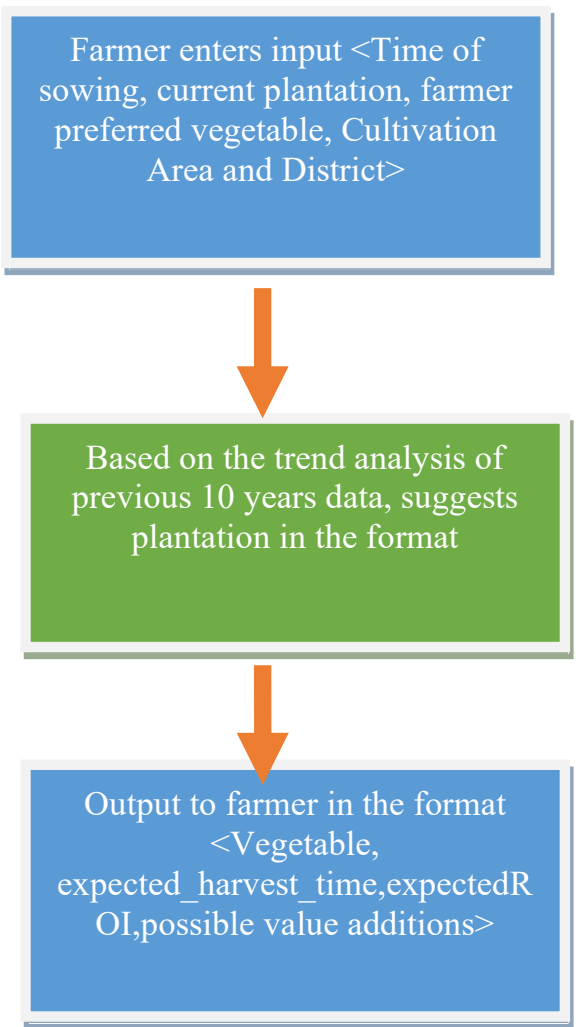

Figure 4. Flowchart for proper plantation for Farmers

$$
\text { - } \quad \text { Cultivation Area }
$$

2. The DSS refers the trend analysis of various vegetables ROI for that particular area and time of the year and suggests plantation decisions

3. The output includes a list of plantation options that include,

- Vegetable Name

- $\quad$ Expected Harvest Time

- $\quad$ Expected ROI

- $\quad$ Possible value additions

sorted in descending order of Expected ROI

The novelty/uniqueness of the proposed application are: Maximum win-win profit mapping between buyers and farmers, Customized plantation recommendations that includes farmer group of interests and live plantation data in the area and Optimal transportation by combining farmers and buyers in the same area and hence deciding.

There are many gaps in existing approaches that are targeted to be covered through this application development. Live plantation data is not used in existing systems to recommend plantation. When small scale buyers are available nearby is not concentrated. Only mandi level optimization is considered in existing systems. Shortest route and aggregating many farmers and buyers in transport can further reduce round trip transport of vegetables there by the retail price.

For example, the vegetables grown in Orathi, Kancheepuram are taken to Koyambedu Wholesale Market Complex which is one of the Asia's largest perishable goods market complex located at Koyambedu, Chennai. The market complex is spread over an area of 295 acres $(1.19 \mathrm{~km} 2)$. The vegetables are then again taken back by agents to Chengalpattu and Madhurantakam areas which are very closer to Orathi, the place of plant cultivation.

The special questionnaire was prepared and the questionnaire content containing questions asked to farmers are,

1. How do you sell your produce?

2. What is the procedure for transportation?

3. Who is the final authority to fix the price for products?

4. Are they ready to sell their product to near by distributers?

5. Are the products cultivated so far?

6. Are they interested in collective farming?

7. Are they ready to supply their produce to house hold functions in small scale?

In that village, farmers selling their produce to two main markets 1.koyambedu and 2.T.Nagar market. They receive less profit in the current scenario. They would like to market their produce in nearby buyers with optimal cost of transportation. They need good price for their produce without chain of intermediates.

\section{Conclusion}

Though the primary occupation of India is agriculture and India is one of the biggest producers of food crops in the world, small and marginal farmers still suffer from marketing issues. Small scale/marginal vegetable farmers do not get a proper return on their investment that is justifiable in terms of retail price. The ministry of agriculture has taken many measures to help the small scale farmers. The ones that we are interested are eNAM (Electronic National Agri Marketing) for marketing and Demic (Domestic and Export Market Intelligence Cell) for plantation. We propose this framework as an extension to these initiatives by including features like optimization techniques for marketing and historical cum live plantation details for plantation. We develop a mobile based decision support system to help small scale/marginal farmers to decide on the crops to plant and also on how to market their produce profitably.

\section{References}

eNAM - https://www.enam.gov.in/web/ 
[2] Demic - https://www.india.gov.in/domestic-and-exportmarket-intelligence-cell-0

[3] eAdangal - https://nesevai.tn.gov.in/eAdangal/

[4] KissanSuvidha - http://www.kisansuvidha.com/

[5] PusaKrishi -http://pusakrishi.iari.res.in/

[6] Agri App - https://www.agriapp.co.in/

[7] Napanta - https://www.napanta.com/

[8] Uzhavan - https://www.tnagrisnet.tn.gov.in/people app/

[9] Plantix - https://plantix.net/en/

[10] Manglaa, S.K, Luthrab, S., Richc.N., Kumar, D., Ranae, N. and Dwivedie, Y.K. (2018) "Enablers to implement sustainable initiatives in agri-food supply chains", International Journal of Production Economics, Elsevier, 203, pp379-393

[11] Li, H. and Wang, J. (2010). "An Integrated Study of Provide Service for Agriculture, Rural Areas and Farmers with the Help of Agricultural Futures Market". Asia-Pacific Power and Energy Engineering Conference, pp. 1-4.

[12] Garrod, G., Ruto, E., Willis, K. and Powe, N. (2014) "Investigating Preferences for the Local Delivery of Agrienvironment Benefits “,Journal of Agricultural Economics, 65(1), pp 177-190

[13] Pham, H.D., Crase, L., Burton, M. and Cooper, B. (2019). "Strategies for integrating farmers into modern vegetable supply chains in Vietnam: farmer attitudes and willingness to accept", Australian Journal of Agricultural and Resource Economics, 59, pp. 1-17.

[14] Rupnik, R., Kukar, M., Vračar, P., Košir, D., Pevec, D. and
Bosnić, Z. (2019). "AgroDSS: A decision support system for agriculture and farming", Computers and Electronics in Agriculture,161 ,pp 260-271

[15] Oliveira,F.B.D. and Ferson, S. (2019). "Methodology for a Risk Assessment Decision Support System in Vertical Farming", EURO MINI International Conference On Decision Support System Technology,

[16] Cunha, M. and Gonçalves, S.G. (2019). "MACHoice: a Decision Support System for agricultural machinery management", Open Agriculture. 4, pp305-321

[17] Ogunti1, E.O., Akingbade1, F.K., Segun, A. and Oladimeji,O. (2018)."Decision Support System Using Mobile Applications in the Provision of Day to Day Information about Farm Status to Improve Crop Yield", Periodicals of Engineering and Natural Sciences, 6(2), pp. 89 99

[18] Ortiz, K.L., Moreira, J.M., Salvatierra, A.A., Morán,M.F., Morstadt, J.C. and García, R.V. (2018). "Decision Support System for the Control and Monitoring of Crops", Second International Conference on ICTs in Agronomy and Environment, Springer Advances in Intelligent Systems and Computing book series, 901, pp 20-28.

[19] Gardasa, B.B., Raut, R.D., Cheikhrouhou, N., and Narkhede, B.E. (2019). "A hybrid decision support system for analyzing challenges of the agricultural supply chain", Sustainable Production and Consumption, Elsevier, 18, pp 19-32 